\title{
THE GEOTECTONIC AND PHYSIOGRAPHIC GEOLOGY OF WESTERN ARKANSAS.*
}

\author{
BY ARTHUR WINSLOW.
}

(Read before the Society August 19, 1890.)

CONTENTS.

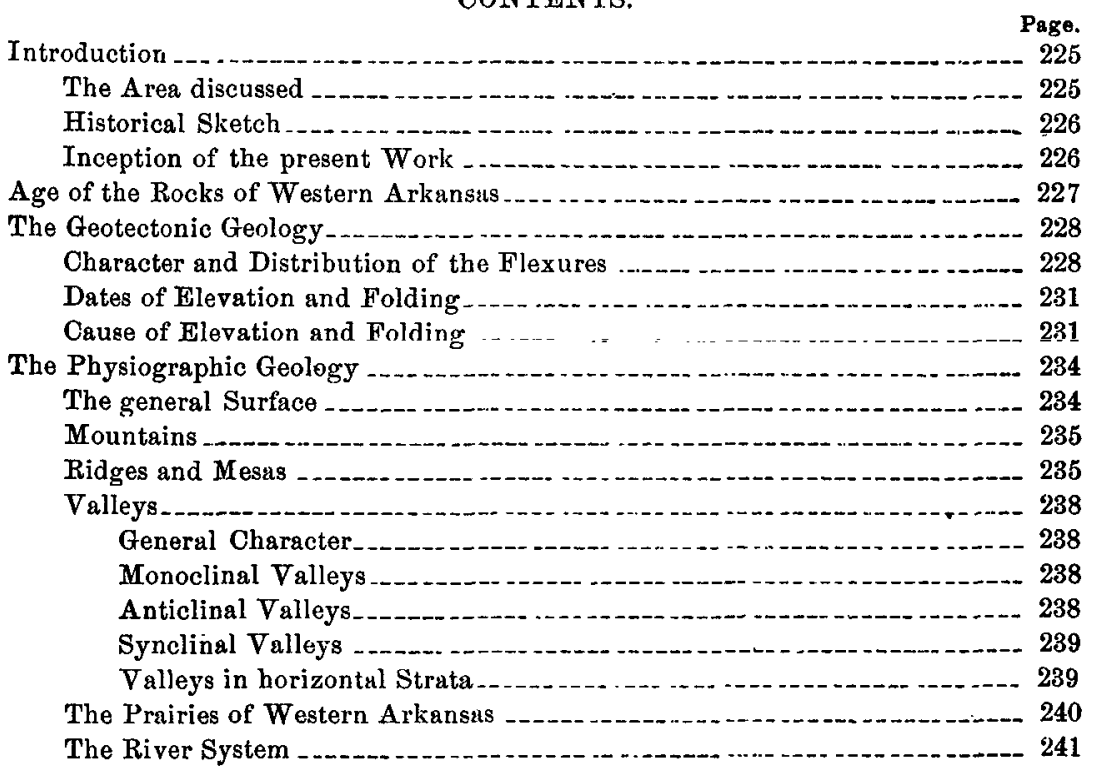

\section{INTRODUCTION.}

The Area discussed.-The following pages refer chiefly to what is known as the coal region of Arkansas. This is in an area situated in the western part of the state, tributary to the Arkansas river. It extends from the Boston mountains on the north to beyond the Poteau and Petit Jean mountains on the south, thus covering an area about 100 miles long in an east-and-west direction by 50 miles broad in a north-and-south direction.

* Published with the approval of Dr. John C. Branner, State Geologist of Arkansas. XXXIV-Bulr. Grol. Soc. Am., Vor, 2, 1890. 
Historical Sketch.-The geotectonic geology of western Arkansas received little or no attention prior to the inauguration of the geological survey of the state now in progress. Shumard, in the report of Marcy's Red river expedition, made in 1854, makes no reference to the subject. In a paper, published in 1854, by Professor J. A. Warder, of Cincinnati, on a Geological Reconnoissance of the Arkansas River, an attempt is made to locate axes of flexure; and some of the conclusions have been confirmed by recent work of the state survey. Marcou touches upon the subject in the report of the Thirty-fifth Parallel survey. One of the most noticeable points in Marcou's interpretation of the geology of western Arkansas is the separation of the contorted slates about Little Rock, which he terms " metamorphic slates," from the overlying sandstones near that place, which he classes as Carboniferous, and which latter, he states, lie horizontally and unconformably upon the former. Beyond this to the westward, all of the various sandstones and shales exposed in the Ozark mountains and the Petit Jean mountains, as well as in the bluffs at Ozark and Van Buren, are included by him in the Carboniferous. This distinction between "metamorphic slates" and Carboniferous shales and sandstones led to some confusion in fixing the age of the uplifts. The horizontal position of the sandstones at Little Rock seemed to Marcou to preclude the idea that the force necessary for the metamorphosis and upheaval of the underlying "slates" could have been exerted posterior to the deposition of the sandstones, while at other localities rocks recognized as Carboniferous had evidently been subjected to such upthrow. He thus adopted an hypothesis of two distinct periods of disturbance, one anterior and the other posterior to the formation of the Carboniferous rocks. Thus the hills at Little Rock, at Hot Springs and at Sulphur Springs are stated to be dislocations anterior to the Carboniferous.

In the reports of the first geological survey of Arkansas, which was prosecuted between the years 1857 and 1860, no attempt is made to delineate geologic structure, and the positions of the anticlines and synclines is referred to only in the most disconnected and incidental manner along with the general descriptions of counties. Failure to consider these features led to most faulty conclusions in the attempt to correlate the rocks of this region with each other, as well as with those of other states.

Inception of the present Work.-When, therefore, in the autumn of the year 1887, $\mathrm{I}$ entered the coal region of Arkansas, preparatory to its study, it was with very vague anticipations; yet these anticipations were not sufficiently vague to preclude surprise, and, as my journey proceeded from point to point, surprise succeeded surprise. The thickness of the rock column which developed itself exceeded all expectations, as did also the number of the beds constituting this column. Instead of horizontal or gently dipping strata such as I expected to find, steep dips seemed to predominate, and the 
directions of these dips varied rapidly. While slowly meandering through the country on horseback, with only an occasional extended view from some peak, each topographic feature presented itself separately, and the differences in size, in outline, in profile and in trend, within comparatively small areas, added to the confusion of conception. It soon became evident that the problems which this country presented could be solved only through detailed work in which delineation of the topography must play an important part. Thus we came to the construction of the detailed topographic maps which are now being engraved, and which will appear in a forthcoming report of report of the Arkansas geological survey.

The small topographic map accompanying this paper, plate 8 , is condensed from these detailed maps. It expresses only faintly, however, much that is shown to be of geological significance on the large sheets. As the construction of these sheets progressed, order began to develop itself; the relations of disconnected parts gradually became apparent; until now, as completed, the maps themselves stand as the solutions of various problems for the solving of which they were originally intended to be only one of the mean. To some of the results of this work I now wish to call attention.

\section{Age of the Rocks of Western Arkansas.}

From the time of Owen's work, preceding the year 1860, the belief has been prevalent that the coal beds and associated rocks of western Arkansas are of sub-conglomerate or lower Carboniferous age. Without analyzing the reasons for this conclusion here, it suffices to say that our present knowledge of the flora of these coal beds, as well as the results of independent stratigraphic studies, lead to the conclusion that the coal beds of the Arkansas river and the associated rocks belong well up in the Carboniferous system. The complete display of the evidence leading to this conclusion is reserved for a future publication, since this question is not properly an essential part of this paper; but in general terms the line of argument is as follows: In northwestern Arkansas, in the vicinity of Fayetteville, Archimedes limestones and other rocks of probable lower Carboniferous age are well developed. Thence southward, across the Boston mountains, several cross-sections have been constructed with the results of proving the existence of barren strata over 1,000 feet in thickness intervening between these limestones and 
the coals of the valley of Arkansas river. The results of one of these sections are embodied in the generalized section, figure 1, and the total thickness of the formations exposed within the area described is there approximately shown. Further, a study, by Mr. G. D. Harris, of the flora of certain coal beds on the Arkansas river, in the vicinity of Russellville, led to the conclusion that they represent horizons above the conglomerate. On stratigraphic grounds these latter beds are placed many hundreds of feet beneath the uppermost beds represented farther west in the state: hence we have reasou for assigning to these latter beds a position well up in the Coal Measures.

\section{The Geotectonic Geology.}

Character and Distribution of the Flexures.-In illustration of the character of the flexures of this area, figures $1,2,3,4,5$ and 6 are presented. Figure 1 is a generalized cross-section through the Boston mountains and

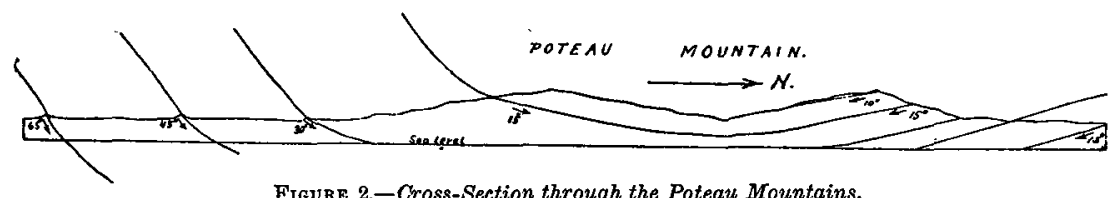

Figure 2.-Cross-Section through the Poteau Mountains.

Scale, horizontal and rertical, 1.6 miles $=1$ inch. Looking westward. Showing the steeper dips northward.

the Arkansas river valley. It illustrates the diminution in intensity of flexing from south to north. This section is constructed along a line running in a direction nearly due north and south, at right angles to the axes of flexures, which are invariably east and west lines, exact or closely approximate. From the Potean mountains northward the flexures are seen first to be intense, and then to diminish until they terminate in the grand monocline of the Boston mountains.

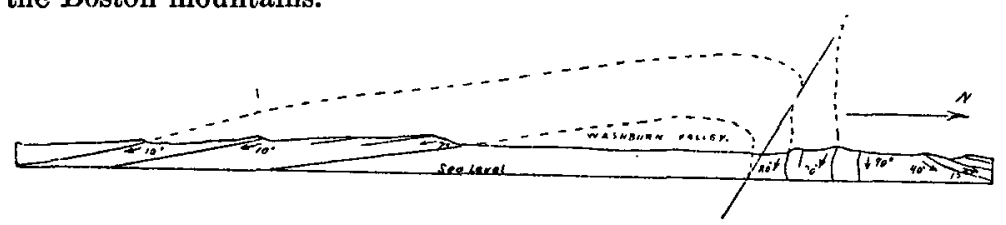

Fraune 3.-Cross-Section through the Washburn Anticline.

Scale, horizontal and vertical, $1.25 \mathrm{mile}=\tau$ inch. Looking westward. Showing overturned fold and fault, Indicating luteral movement from the south.

Figure 2 is a section constructed on equal horizontal and vertical scales across the Poteau mountains. It illustrates not only the excessive dips of the south, but also the general fact of the greater inclination of northward dips over southward dips.

The last condition is also illustrated by figures 3 and $4:$ the former repre- 
sents a section across the great Washburn anticline and the interesting series of ridges southeast of Greenwood; the latter a similar section across Backbone anticline, an analogous flexure and series of ridges west of Greenwood. The overturn of the fold is well marked in both of these cases ; in fact, the flexure has passed to the extreme condition of a fault with an upthrow on the southern side, which toward the termini of the anticline diminishes to nothing. The character of these flexures and faults is typical of that attributed to lateral compression.

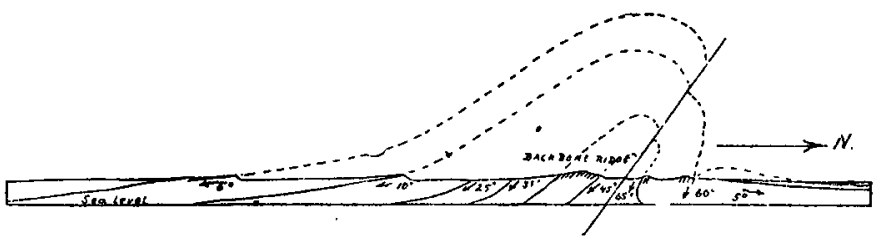

Fraure 4,-Cross-Section through the Backbone Anticline.

Scale, horizontal and vertical, 1.25 miles $=1$ inch. Looking westward. Showing overturned fold and fault, indicating lateral movement from the south.

Finally, figures 5 and 6 are sections across the southern base of the Boston mountains, illustrating the general synclinal plunge of the strata before they rise in a monoclinal arch to form the Boston uplift. It is probable that along with the production of the monocline some faulting took place, evidence of which is presented by abrupt rock-faces, with smooth surfaces, found along the foot of the mountains in the line of the flexure, sometimes

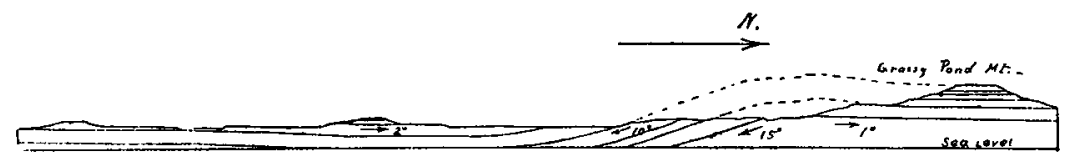

Figure 5.-Cross-Section into the Boston Mountains.

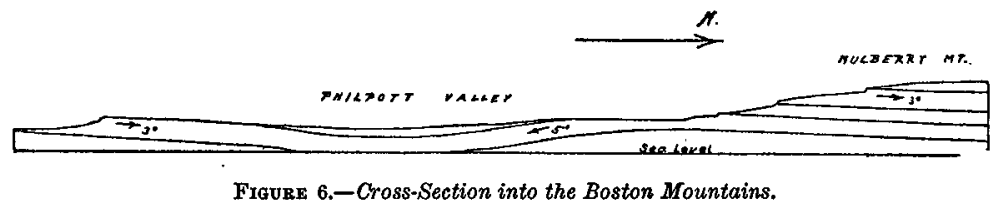

Scale, horizontal and vertical, 1.15 miles $=1$ inch. Looking westward. Showing monoclinal flexure along the southern base.

accompanied by chalybeate springs; but the throw was probably slight and the horizontal extent short. Thence northward the strata dip gently southward or lie flat almost uninterruptedly, as shown in figure 1. 
A study of these sections leads, therefore, to the conclusion that there was lateral movement and that this movement was from the south. A consideration of the horizontal extent of the flexures and of their distribution develops also many suggestive facts. The axes of the flexures are located on the topographic map accompanying this paper, and their topographic relations can be well studied there. Perhaps the most striking feature is the great number of distinct flexures represented in so small an area ; but the lack of persistency in the plications, some of which are of great intensity, also demands attention. Thus, the anticlinal arch north of the Poteau mountains, termed the Coops anticline, which, opposite the middle point of its axis, is characterized by dips ranging from $10^{\circ}$ to $20^{\circ}$, disappears eastward within a distance of about five miles and is immediately followed, in the prolongation of its axis, by the Magazine syncline, the plication being transferred to the Belva anticline on the south, the axis of which runs parallel to that of the Magazine syncline. The Washburn anticline illustrates this feature in a still greater degree. Here, within a distance of five miles from a section of $80^{\circ}$ dips, the flexure disappears entirely, and in the prolongation of its axis westward there is a plateau in which the rocks are in a nearly horizontal position. The Backbone anticline, which is also characterized by excessive northerly dips, together with some faulting, terminates similarly toward the east at Greenwood, and in the position of its prolonged axis the rocks dip uniformly southward at angles of only a few degrees. The Biswell anticline, northeast of Greenwood, dies out westward and eastward within a distance of four miles from its center, and the Potato hill syncline is exactly in the line of the eastward prolongation of its axis. Along the southern foot of the Boston mountains, the synclinal flexure already mentioned and illustrated is seen to be composed of a series of short flexures which, in places, overlap each other.

Thus, in general terms, an interlocking system of flexures is produced. Invariably, where one of prominence begins to die out another of the same character begins to assert itself, either toward the north or toward the south, and generally a flexure of opposite character is developed in the prolongation of the axis of the expiring one. The plications thus seem to be, to a certain extent, compensatory; the relief from strain afforded by the flexing along one axis being supplied by the folding along a contiguous axis, while the first disappears.

From the last consideration it seems probable that developed cross-sections of the same bed across this area would have approximately the same length; though, even if this were so, such a result depends upon too many indefinite factors to be of much value. But, however exact such cross-sections might be, their mere development would not replace the strata of this flexed area in their original positions and relations. A restoration by stereogram of 
the flexures here involved, even according to the most conservative interpretations, would produce a surface on which the features of relief would be elongated ellipsoidal domes-it would be a typical warped surface, and, like other warped surfaces, could not be developed into a plane.

Dates of Elevation and Folding.- From the age assigned these rocks, it follows that the date of their elevation must have been post-Carboniferous. Further, the evidence is strong that this elevation was pre-Mesozoic; for, firstly, no Triassic or Jurassic rocks are found overlying these Carboniferous beds conformably; and, secondly, Cretaceous beds rest unconformably upou and in contact with the upturned edges of the Paleozoic beds along their southern border, the Cretaceous beds showing little or no evidence of disturbance; which latter fact demonstrates also that the folding, or at least such portion of the folding as was wide-spread in its effects, antedated that period. But the question whether the elevation and the folding were exactly simultaneous or whether the latter succeeded the former is a detail concerning which we have not complete evidence to present here. The existence of a disturbance in post-Cretaceous times is well established through the study of the eruptive rocks of the state, which are of post-Cretaceous age; but its effect in flexing the Coal Measure rocks seems to have been insignificant. According to Branner:*

"The Cretaceous rocks have not been much disturbed or altered, even where the eruptives come up through them. Neither can it be positively stated that the eruptives greatly disturbed the Paleozoic rocks through which they pass, for the folding, crushing, and metamorphosis seem to be just as marked away from the outbursts as in their immediate vicinity."

General considerations of the magnitude of the movements involved, and of the character and comparative values of the different mountain-making epochs in the history of this continent, incline one to the belief, however, that the folding as well as the elevation of these Carboniferous rocks of Arkansas was synchronous with the movement which gave birth to the Appalachians, and that the similarity between the structure of this area and that of the Carboniferous area in Pennsylvania is not a mere accident but is due to a trans-Mississippian extension of the same cause.

Cause of Elevation and Folding.-As above expressed, the flexing of the strata in the coal region of western Arkansas is essentially Appalachian; and, reasoning from resulting forms, any explanation good when applied to the Appalachians will be good when applied here. A study of the various flexures reveals many features which call for compression and lateral movement. The influence of secular contraction in this movement cannot be discussed exhaustively until the results of studies elsewhere in the state are available; but, in view of the questioned adequacy of this cause, an attempt 
is made here to harmonize the phenomena with the cause, advocated by Reade,* found in expansion of the lower layers by rise of the isogeotherms.

Immediately preceding the date of elevation there was, over what is now southeastern Missouri and northern Arkansas, a land area of pre-Carboniferous rocks, southward from which extended the seas in which the Carboniferous rocks were laid down.' In Missouri the total thickness of the Paleozoic strata is estimated by Broadhead to be in the vicinity of 5,000 feet. In Arkansas the thickness must be many times this, that of the Carboniferous strata of the Arkansas river valley alone being about 10,000 feet. The rocks of these Arkansas strata, sandstones, and shales bear evidence in the form of ripple marks and mud cracks of having been chiefly shallow-water deposits; hence the subsidence was both profound and gradual. An elevation of great magnitude succeeded this subsidence. The Arkansas area thus yields another illustration of a frequently observed sequence of a great orographic movement following a period of long-continued and abundant deposition. The thickness of the strata which accumulated during this period must have been great enough to allow a decided increase of temperature of the lower members, and the explanation of the subsequent movements by expansion through this increase of temperature thus finds undoubted support in this particular.

The sections represented on preceding pages yield evidence that a movement,from the south accompanied the plicating action. The explanation to be offered for this is, that the region of most energetic plicating action was south of the area here especially treated. Excessive dips and an incipient metamorphosis of the rocks characterize a belt of country running in an east-and-west direction some twenty-five miles south of this area. It was in this same belt that the post-Cretaceous disturbance already referred to was most active. This last disturbance was accompanied by the formation and intrusion of igneous rocks; but none such have been recognized as accompanying the general upheaval of post-Carboniferous date.

The facts point thus to the conclusion that this belt was characterized by disturbances from post-Carboniferous to post-Crètaceous times. According to the theory of expansion, this belt was the one along which great tension was first developed in the upper layers from the great elevatory movements caused by the expansion of the lower layers. Through continued action of these causes the upper layers were fractured or stretched and the highly plicated lower layers, which were subjected to pressure, were protruded. The intrusion of molten rock in post-Cretaceous times was but the culmination of this action. On this interpretation we can understand how lateral movements of the rocks have been produced northward from this axis of disturbance; how the development of strong plications here gave relief to the 
strain in the lower layers; and how the intensity of the flexing diminishes away from this line northward to the Boston Mountains, as illustrated by figure 1.

But, in addition to presenting evidence of lateral movement, the warped character of the structure of the Arkansas valley, described on page 230, suggests the action of other causes. To produce such a warped surface, a considerable vertical and upward component in the force acting is necessary. The shells of successive strata constituting these quaquaversal arches must have been stretched or elongated. Gilbert has explained how this was produced by laccolite intrusion in the formation of the Henry mountains.* Here we have no reason to suspect the proximity of such masses of igneous rock. Conditions can be conceived by which lateral compression from two directions might alone produce this; but equally well, if not better, can we attribute this warping to expansion of the lower strata through an increase of temperature due to a rise of the isogeotherms with continuous sedimentation, as explained by Reade. A condition of tension in the upper layers would thus be produced; the topmost of these layers would be fractured and pulled asunder; the lower lying ones would be compressed and caused to flow and spread under the influence of great pressure. The amount of fracturing and the amount of spreading in any one case would be dependent upon the elasticity and the plasticity of the layer and upon the amount of pressure it is subjected to. The plications would thus represent the combined effects of two causes: Firstly, to the action of the general cause of expansion of the lower beds is due the production of the warped surface; secondly, to the superior activity of this first cause in the region to the south is due a lateral movement towards the north which, acting as a secondary cause, produced unsymmetrical folds and lateral compression of the rocks.

In connection with this question of the origin of quaquaversals, a suggestion is in place relating to the value of developed cross-sections constructed from observed dips. From such cross-sections the amount of linear compression in the plications of the Alps has been estimated at 72 miles, and in the case of the Appalachians at 88 miles. These figures have been criticised by geologists and thought to be excessive-more than the supposed causes were adequate to produce.

On the assumptions that the rocks are in a state of strain; that the upper layers of an arch are in a condition of tension; and that the bulging is produced by an effort of the compressed lower layers to protrude themselves, the top layers would undoubtedly be fractured. The forces of degradation would attack the arch vigorously along the lines of such fractures, would gradually remove the dome-like cover, and would then proceed to cut further down into the core. Such cutting means, however, removal of material,

*Geology of the Henry Mountains, 1877, p. 76.

XXXV-Bulu. Geol. Soc. Ar., Vor. 2, 1890. 
and this means gradual relief from pressure of the underlying rocks; hence a constantly diminishing load opposes the forces tending to cause protrusion of the lower layers. Thus it is conceivable that expansion or protrusion may take place coincidently in a general way with the removal of the load. An immediate effect of such protrusion would be to increase the dip of the rocks adjacent to it, as is illustrated by figures 7,8 and 9 , which are ideal sections across such an arch. They show the successive changes of dip with the progress of degradation. The effect of such an interpretation of the origin of dips upon the represented length of a flexed stratum will be at

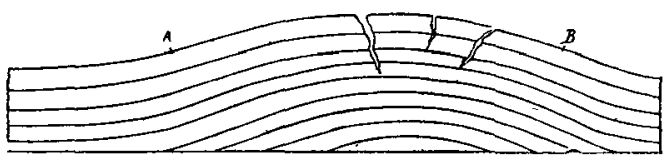

Figure 7.-Ideal Section of Arching Strata. First Stage.

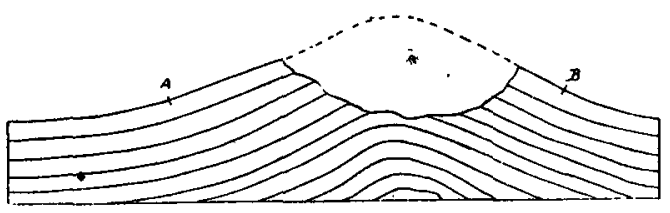

Fiaure 8.-Ideal Section of Arching Strata. Second Stage.

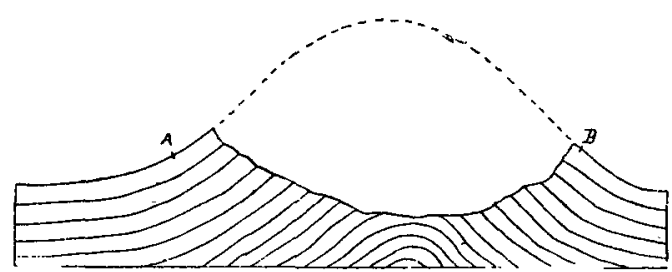

Fiqure 9.-Ideal Section of Arching Strata. Third Stage.

Ideal sections illustrating the progressive increase of dips with progressing degradation.

once appreciated. In figures 7,8 and 9 the relative lengths of the lines connecting the points $A$ and $B$ are respectively 23,25 and 30 . May not the apparently excessive estimates of linear compression in many instances have been due to such a cause?

\section{The Physiographic Geology.}

The general Surface.-The surface features of western Arkansas are typically those of stratified non-metamorphosed rocks, and their mode- of production has been such as usually characterizes such rocks. The stage of topographic development here may be classed as mature, in that it includes 
great variety of form, from the cascade condition of the mountains to the broad base-level condition of the river bottom.

The ranges of level are not very great. From Fort Smith eastward the Arkansas river falls at a rate of about a foot to the mile, the altitudes being, at Fort Smith, about 430 feet; at Dardanelle, about 320 feet; at Little Rock, about 260 feet. The highest summit is that of Magazine mountain, which reaches an altitude of 2,850 feet.

Mountains.-The mountains vary in profile and plan according to the position and character of the strata composing them. The Boston mountain area on the north may be classed as an elevated plateau cut by deeply corraded channels. The general altitude is between 1,000 and 2,000 feet. The surface is undulating and, at a number of points, rises to summits several hundred feet above the surrounding country. The component rocks are grits, sandstones and shales; and in the northern portion limestones appear near the base. These rocks lie generally in a horizontal or slightly inclined attitude. Towards the south the mountain mass in places slopes gradually to the level of the river, but elsewhere it rises abruptly from the valley, presenting bold escarpments of massive sandstone along several benches; the mountain front is notched by ravines and hollows setting back into the plateau.

The mountains immediately south of the Arkansas river include the Sugar Loaf mountain, Poteau mountain and White Oak mountain. These are members of a system which extends westward into Indian Territory, and eastward, with somewhat irregular grouping, to the Arkansas river at and below Dardanelle, including such ranges as the Petit Jean and the Magazine, and such outlying masses as Mount Nebo and the Short mountains. The trend is approximately east-and-west in all cases. These mountains are of horizontal or flat synclinal strusiture, and are made up of alternating beds of sandstones and shales. They are, in many cases, typical illustrations of mountains of circumdenudation, notably Sugar Loaf mountain, Magazine mountain, Spring mountain and Mount Nebo. The elevation of the summits varies from about 1,000 feet to 2,850 feet above tide. They have generally very steep slopes, though these are frequently broken by benches formed by resisting layers of hard sandstone, which often stand out from the mountain side in abrupt escarpments. The crest is often a flat table-land, and this, as well as the benches on the sides, are frequently cultivated. Timber exteuds to the very summits of these mountains, though at the higher altitudes it is small and stunted.

Further southward, as the region of greater disturbance is approached, the mountains consist of steep-dipping strata, more or less metamorphosed; such mountains are those of the Rich Fork, Black Fork and Fourche ranges.

Ridges and Mesas.-The mountains are the more prominent, the grander features of the topography; but the ridges and mesas of this area far exceed 
the former in geologic interest. In height these hills vary from low mounds, 20 or 50 feet high, to diminutive mountains, 400 or 500 feet above the surrounding country. As a rule, however, the height does not exceed 200 feet, and the average ridge is in the neighborhood of 150 feet high.

The distinction between ridge and mesa implied by the above heading is based upon a difference in cross-section which admits of this division of the minor elevations into two classes. The first class, or that of ridges, includes those long, sharp-crested monoclinal backbones with no summit areas and whose sides slope immediately away from the crest in both directions. Sometimes both slopes are steep, but generally one is precipitous and rocky while the other is gentle and adapted to cultivation. The second class, or that of mesas, refers more particularly to flat-topped or gently sloping and undulating elevations of horizontal structure, approaching the character of plateaus, with steep sides partially or wholly surrounding the broad summit. This distinction, based upon structural differences, is by no means a rigid one, and the two classes are found to merge by insensible gradations.

The distribution of these ridges and hills, though obedient to the laws of geologic structure, is subject to so many modifications through influence of stratigraphy and erosion that, without careful study, all seems chaos. By reference to the map it will be seen, however, that what are distinguished as ridges ean be generally grouped into a system, the members of which run in long parallel lives with intervening narrow valleys. These members are frequently broken by gaps, vary considerably in height and prominence, are squeezed together, appear to die out, curve around in loops, and coalesce to form one flat-topped, canoe-shaped end. Throughout these changes, however, each ridge can be recognized in all its different phases, and the idea of order is traceable throughout; while with the plateau-shaped hills the distribution is as irregular as the outline is varied, and the characteristics of form might almost be called accidental.

Another type of hills, commonly known as "potato hills," may properly be termed cones. They are of conical shape, slope steeply on all sides, and are generally made up of shale with, perhaps, a sandstone cap. They properly represent the last stage of erosion of the mesa.

Immediately north of the Poteau mountains there is a system of monoclinal ridges, composed of sandstone strata dipping toward the mountains; near the mountains, and especially along the larger drainage channels, they are some. times well-nigh obliterated by the combined effects of torrential flows and the accumulations of mountain débris. Outside of such areas, however, they are easily traced, and their topographic persistence is often remarkable.

Coops ridge, a few miles north of the Poteau mountains, is especially worthy of notice on account of its isolated position and the peculiarity of its structure. It is evidently the remains of a quaquaversal arch of elliptical 
outline, of which arch the dome has been eroded and the underlying shales eaten out, so that now only a monoclinal rim is left. The height of the ridge varies, and the crest line is broken in places into a succession of small peaks; the greatest altitudes are at the termini of the anticlinal curve.

The system of ridges immediately north of Coops ridge is particularly well-marked; the rocks here dip northward at an angle of about $20^{\circ}$, but eastward this dip flattens and the ridges terminate in typical canoe-shaped points.

Jennings hill and the ridges which surround it in concentric ellipses are beautiful developments from a synclinal structure. These ridges are all monoclinal, and are composed of sandstones, underlain by shales dipping $5^{\circ}$ to $10^{\circ}$ convergently toward the common center line of the series of ellipses.

Of chief prominence among the ridges are those which flank the Washburn valley, on each side of the anticlinal axis. The inverted canoe-shaped connection of the two systems at the western end is boldly brought out both by the elevation of the ridges at this point and by their sharply defined outlines. Toward the east, some of the ridges of marked prominence die out or become relatively insignificant, an undoubted indication of a concomitant thinning of the hard layers, to which these ridges owe their prominence elsewhere.

A similar system of ridges is that of which the eastern termination is at Greenwood. It follows in the same way a strong anticlinal flexure; but on account of the faulting which accompanied this flexing (see figure 4, page $229)$ the ridges north of the axis are not always of prominence.

Many other instances of similar ridges might be cited and their local characteristics referred to, but such detail would be out of place here. Enough has been said to direct attention to the existence and character of these features of relief; their distribution and special characters can be studied on the map.

North of the Arkansas, between it and the Boston mountains, the character of much of the topography is essentially different from that last described, and from that south of the river geverally : the hills are closely crowded, their outlines are very irregular, they have no uniformity in trend, and the slopes are gentle or steep, according to the meanderings of a capricious drainage system. The shales and sandstones, so common elsewhere, make up these hills, and they are generally capped by beds of the latter. As may be inferred, no pronounced and persistent dip of the strata characterizes this region. The angle of dip seldom exceeds $5^{\circ}$, and the direction is fluctuating. In short, the topography here is typically such as results from erosion in heterogeneous strata which lie in a horizontal position. The region north of the river has been one of repose, and erosion dominates stratigraphy; that south of the river has been one of disturbance, and stratigraphy asserts itself in the topography. 
Valleys: General Character.-The greater part of the area treated in this paper may, in a broad sense, be considered part of one great valley-that is, as constituting part of a single drainage basin, bounded on the north and south by mountain ranges. It is here intended, however, to treat of valleys in a more restricted sense, as those depressions which intervene between and are complementary to all the individual mountains, ridges, and other minor elevations which have already been described. With reference to the geologic structure these valleys may be classed as follows: 1. Monoclinal valleys; 2 . Anticlinal valleys; 3 . Synclinal valleys; 4 . Valleys in horizontal strata. With reference to surface detail, to soil, to vegetation, each and all of these various classes may be, in whole or in part, either rugged, undulating, or flat; may be wet alluvial bottoms, or dry loamy or rocky uplands ; may be densely covered with forest growth, or may be prairies.

Valleys of the first three classes preëminently characterize areas of regular flexing of heterogeneous, non-metamorphosed strata. In regions of great contortion and rock crumpling, stratigraphic divisions have a too intricate distribution to control corrasion; in homogeneous strata, degradation is general and uniform, and there are no guiding planes to direct the forces of erosion along the lines of least resistance; and metamorphosed strata, even when not contorted, possess in a great degree the attribute of homogeneity and offer approximately equal resistance in all directions to degradation. The predominant rocks of western Arkansas are sandstones and shales. We have seen that sandstone is the distinctive ridge-forming material. Similarly the fissile, easily eroded shales underlie the valleys almost without exception.

Monoclinal Valleys.- These are the depressions between parallel monoclinal ridges, and agree with them in trend. Examples of such valleys are to be seen between the parallel ridges north of the Poteau mountains. Where such coalesce at the point of an anticlinal they broaden correspondingly and are bounded by steep walls of converging ridges, giving the valleys slipper-shaped outlines. At the terminus of a syncline a broadening takes place by a similar coalescence, but the valley here differs from the last in being bounded by converging ridges which present their gentle slopes towards the intervening depression.

By far the best development of monoclinal valleys, however, is between the members of those prominent systems of ridges which lie immediately worth and south of Washburn valley. On the south side, near the eastern end of the area mapped, these depressions are neither deep nor broad, by reason of the thinning of the ridge-forming sandstone; while at the western end, the several valleys of the southern system sweep around in beautiful parallel curves and, by reason of the compression and verticality of the strata at this point, coalesce with a single valley of the northern system.

Anticlinal Valleys.-These, like monoclinal valleys, are depressions, generally between monoclinal ridges; but unlike those, both bounding slopes are 
across the stratification. In a region of great rock flexures the larger valleys are generally of this type. This area is no exception to the rule. The Hartford valley, in Sebastian county, is a remnant of a grand anticlinal valley; the Poteau mountain range forms its southern boundary, but of the northern border ridge only a fragment is left in Sugar Loaf mountain. The valley north of Sugar Loaf mountain is a similar remnant. Such valleys as these, however, are what may be called primary valleys, their surfaces being broken by ridge lines, between which lie secondary valleys of monoclinal or anticlinal form. The terminal anticlinal valleys resulting from the fusion of two such secondary monoclinal depressions have already been referred to. Examples of purely anticlinal shape are Coops prairie, surrounded by Coops ridge; and Washburn valley, occupying the center of the anticlinal arch of the same name. Such valleys are, however, rare here, and, as compared with the number of monoclinal valleys, the same may be said of all regions, including even those where numerous folds of the strata are developed; for each such fold can exhibit only one anticlinal valley which will be centrally located along the axis of flexure, whereas each distinct and persistent stratum of hard material affected by such flexure will be developed by erosion into a dividing ridge between two monoclinal valleys.

Synclinal Valleys.-These are both topographic and stratigraphic basins, formed, generally, by convergently dipping strata of monoclinal ridges. Complete and unbroken valleys of this type are exceedingly rare. The valley in the eastern extension of Sugar Loaf mountain is of this type, as is also that which extends from Greenwood westward. Other illustrations are the Potato hill prairie, the Philpott coal basin, and the Ouita coal basin.

Valleys in horizontal Strata.-These valleys differ from each of the three classes heretofore described in the extreme irregularity of their outline. No normal plan for such depressions exists. The typical cross-section is that of a flat plane bounded on both sides by abrupt escarpments, $i . e$., is similar to the cross-section of an anticlinal valley. When of oblong shape they follow no prevalent trend; their directions are adventitious. Laterally, resistance to erosion is equal in all directions, and hence their growth is in all directions at a rate dependent entirely upon external çonditions. The cañon, the narrow gorge, is the rudimentary form of a valley in horizontal strata. The intense corrasive energies of degradation are first spent before the slower processes of erosion and sapping show their effects in lateral degradation.

A gorge of this type is that of James' fork, south of Hackett City. Massard prairie, south of Fort Smith, may be considered an example of a valley eroded out of horizontal strata. Slight undulations in the rocks exist here, but are not sufficient to lend form to the valley. The characteristic irregularity of outline, as defined by the bounding ridges on the north and south, will be particularly noticed. It is an old valley; corrasion is no longer 
dominant, and lateral erosion has advanced far. The valley in which Russellville is situated may also be included in this class.

The Prairies of Western Arkansas.-Prairies are generally subordinate valley features, and are properly mentioned here. They are not the broad level tracts of country which are generally implied by the term prairie, and of which the prairies of Kansas are familiar examples. They cover conparatively small areas. Their surfaces may be flat or undulating, or may be diversified by knolls and small ridges. The absence or scarcity of trees is the essential distinguishing characteristic. The prevalent underlying rock of these prairies is always dark shale, which becomes exceedingly fissile and soft on weathering. Thin strata of sandstone occur with this shale, and these generally explain the existence and distribution of the various elevations. The characteristically rounded contour of a soft shale country rock is, however, dominant in the topography. A clayey soil exists frequently to a depth of several feet, and this is apparently derived directly from the shales by decompasition in situ. In places, however, the bare shales are exposed immediately at the surface. The vegetation is chiefly a coarse grass, which is high and luxuriant when not not cropped short and trodden down by cattle. Clumps of small sassafras trees and haw bushes are also often seen and, along the streams, willows, oaks, and other trees attain full size.

The maintenance of these prairies, and probably also their origin, may be explained as due to a combination of causes; namely, the alternation from an extremely cold, wet soil during the rainy season, to a dry hard soil in the dry season, and further the periodic recurrence of prairie fires which shrivel such young tree growths as overcome the obstacles inherent in the soils. In support of this hypothesis is the fact of the occurrence of small bunches of trees over the small prairie knolls, which, being raised somewhat above the surface, have never so cold and water-soaked a soil as the surrounding ground; also the growth of trees along the drainage channels, where there is more moisture in the dry season and where the conditions are generally more uniform. Once started, however, a growth of trees continues to flourish despite all the adverse conditions; for with the commencement of tree-growth the adverse conditions disappear. Hence it is that areas are found which show evidence of having once been prairies but are now timbered lands. Further, these prairies are now great open ranges for cattle, the grass is kept short, and there are no longer such fierce periodic conflagrations; consequently, in places, the growth of trees spreads rapidly over the surface.

A peculiarity of surface detail which often excites notice is the existence of numerous small, low mounds which occur over these prairies, sometimes in great profusion. In diameter they are generally under 50 feet, and in height 
less than 4 feet above the general level, with a profile approximately of turtle-back shape. In distribution they are most abundant over the lowerlying and more level areas. They are generally not arranged in any special order, but lie scattered promiscuously at varying intervals. At times, however, they are seen in rows, which arrangement makes them much more conspicuous and heightens the artificiality of their appearance. The material of these mounds seens uniform throughout and is essentially the same as the surrounding soil, though of somewhat superior fertility. It is opener, lighter and apparently richer in organic matter. Here the grass grows most luxuriantly and clumps of bushes or small trees are often found. Neither in the arrangement of the material nor in the contents of these mounds is there evidence of the agency of man in explanation of their origin. The mere fact of their great number would preclude this. They stand simply as products of a gentle erosive action in soft homogeneous material. Their surfaces represent a former general level. Their material is the old top soil. The intervening depressions are caused by the slow soaking and solvent action of rain accompanied by a gentle flow.

Prairies are scattered over nearly the entire area illustrated on the map, and an enumeration of them all would be impracticable here. Notable instances are: French prairie, at the western terminus of the Washburn anticline; Long prairie, north of the Backbone anticline; Massard prairie, south of Fort Smith; Potato hill prairie, south of Charleston; Grand prairie, north of Charleston; and the prairies east of Russellville.

The River System.-The river system of this area is a theme worthy of a separate chapter. Its evolution and the adjustment of the courses of the different streams will not be discussed here, as this would expand the paper beyond reasonable limits. A few points of interest in this connection may, however, be referred to.

As already stated, this region may be considered as having attained the stage of topographic maturity. The Arkansas river has about reached its base-level; the flow is even and not swift; there are no falls nor bars nor rapids over rocky bottoms, and a layer of sand or silt generally intervenes between the water and the underlying rock; corrasion has about ceased and the stream is extending its alluvial plains laterally. Of a previous stage of base-leveling there is more than a suggestion in the approximate uniformity in height of the majority of those elevations which we have termed ridges and mesas. To fully realize this, however, a careful study of the detailed topographic sheets is necessary.

The rocky gorge through which the Arkansas flows, gives it, in places, the character of an antecedent channel. This is especially noticeable at a point about thirty miles below Fort Smith, where the bluffs on either side for a distance of nearly ten miles come down to the water's edge almost continuously. 
A valley of shales a few miles south of this offers opportunity for a shortening of the channel through easily corraded material; yet the river cannot escape from its inherited bondage between mountain walls. Another instance is just above Dardanelle. The gorge here is only a few miles long, but is particularly interesting in that it cuts straight across the point of a sharp syncline; a feature of flow of a decidedly antecedent character.

Of monoclinal shifting of channels, there is abundant evidence in the evenness in slope of the sides of many monoclinal ridges. In some cases this slope conforms exactly with the dip of the underlying sandstone, and in places this sandstone is almost as bare as when left by the stream as the channel gradually shifted down the slope of the rock.

The courses of the stream across the ridge systems are always nearly at right angles, while they run length wise in the longitudinal valleys, thus illustrating the tendency of waterways to escape from hard strata and to abide in soft, as indicated by Gilbert.

Of backward headwater erosion most of the anticlines seem to furnish evidence. The valley enclosed by Coops ridge seems indisputably a result of this action.

An interesting case of the reädjustment of channels is presented by Petit Jean creek along the Jennings hill syncline. The stream at one time evidently followed the axis of the syncline, as is indicated by the succession of notches along the line through the encircling ridges. From this central channel it has evidently been diverted to the one it now occupies, north of the monoclinal ridge, by the tapping action of a stream which flowed originally as a tributary in this valley of soft rock. 


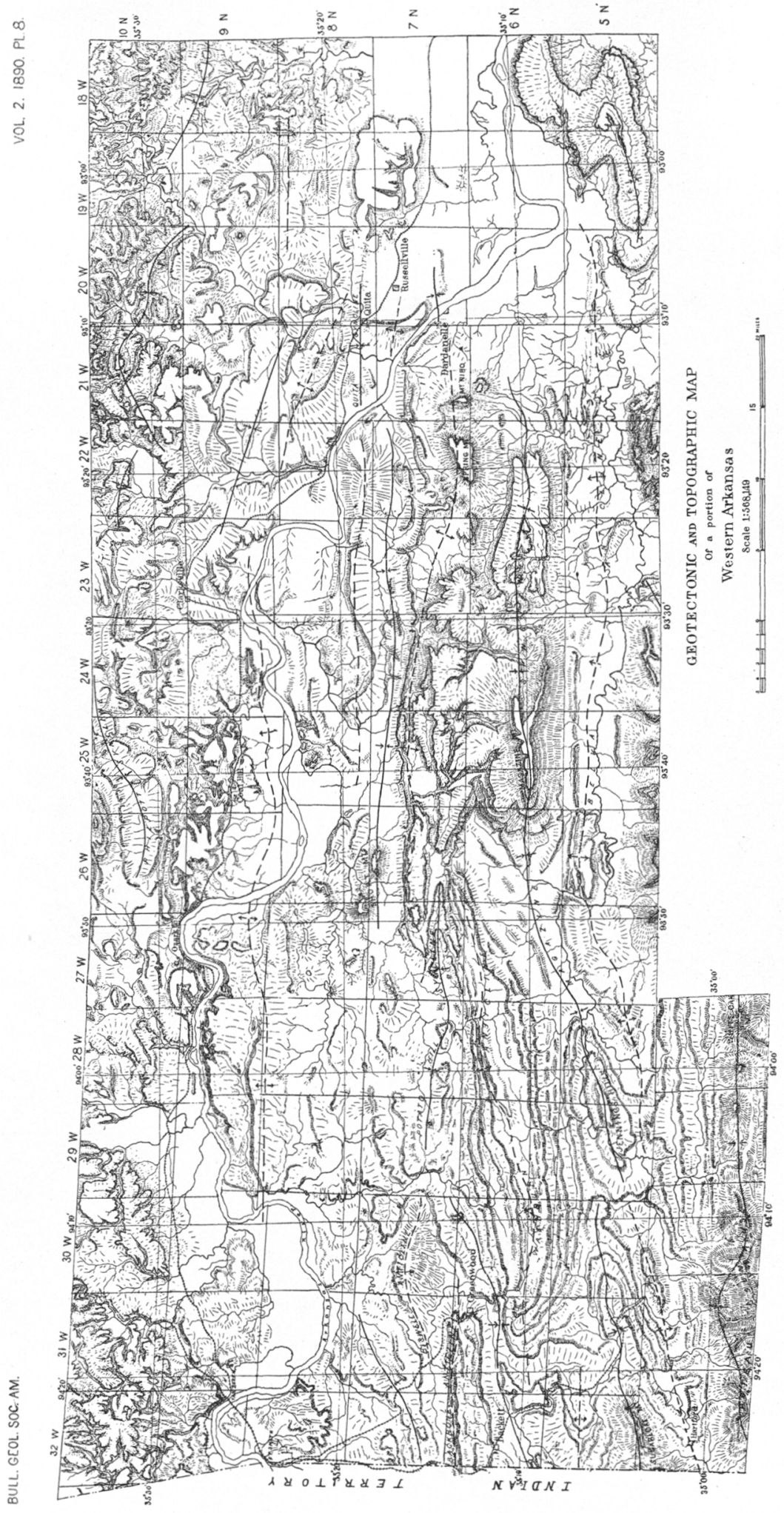


